\title{
Syntaxin, but not soluble NSF attachment protein (SNAP), biosynthesis by rat pancreatic islets is regulated by glucose in parallel with proinsulin biosynthesis
}

\author{
S. Nagamatsu ${ }^{1}$, Y.Nakamichi ${ }^{1}$, H. Katahira ${ }^{2}$ \\ ${ }^{1}$ Department of Biochemistry, Kyorin University School of Medicine, Mitaka, Tokyo, Japan \\ ${ }^{2}$ Department of Internal Medicine III, Kyorin University School of Medicine, Mitaka, Tokyo, Japan
}

\begin{abstract}
Summary Recent studies have revealed that soluble $\mathrm{N}$-ethylmaleimide sensitive factor attachment receptor (SNARE)-related proteins, originally identified in neural tissues, are also expressed in pancreatic beta cells. In this study, we investigated the effect of glucose on syntaxin 1 and $\alpha / \beta$ SNAP biosynthesis in pancreatic beta cells and we demonstrated that syntaxin 1 , but not $\alpha / \beta$ SNAP biosynthesis by rat isolated pancreatic islets was stimulated specifically by glucose nearly in parallel with proinsulin biosynthesis. Stimulation of syntaxin 1 and proinsulin biosynthesis by glucose was dose-dependent $\left(\mathrm{K}_{\mathrm{m}}=\right.$ $\sim 8 \mathrm{mmol} / \mathrm{l}$ ) and reached the maximum (about 8 12 fold) at concentrations over $11 \mathrm{mmol} / \mathrm{l}$. In contrast, $22 \mathrm{mmol} / \mathrm{l}$ glucose increased $\alpha / \beta$ SNAP biosynthesis about 2-fold only, similar to the increase in
\end{abstract}

total protein synthesis. Stimulation of syntaxin 1 biosynthesis by glucose was also time-dependent, taking around $3 \mathrm{~h}$ to reach the maximum, and was not affected by actinomycin-D, suggesting regulation at the translational level. On the other hand, glucose had a similar stimulating effect on both syntaxin 1 and $\alpha / \beta$ SNAP biosynthesis by mouse insulinoma $\beta T C 3$ cells as it did on proinsulin biosynthesis. The evidence showing coordinated stimulation of syntaxin 1 and proinsulin biosynthesis by glucose in rat islets suggested the critical functional role of syntaxin 1 in the insulin exocytotic mechanism. [Diabetologia (1997) 40: 1396-1402]

Keywords Syntaxin, SNAP, insulin biosynthesis, SNARE, glucose.
The process of insulin exocytosis is thought to be divided fundamentally into two stages. The first involves glucose transportation into the cells, where it is metabolized and the metabolite increases the intracellular $\mathrm{Ca}^{2+}$ concentration ( $\left.\left[\mathrm{Ca}^{2+}\right] \mathrm{i}\right)$. During the later stage, the secretory vesicles move to the plasma membrane, where they dock, fuse and release their contents into the extracellular space as a result of the elevated $\left[\mathrm{Ca}^{2+}\right]$ i. Recent advances in brain research have

Received: 16. April 1997 and in revised form: 19 August 1997

Corresponding author: S. Nagamatsu, M.D., Department of Biochemistry, Kyorin University School of Medicine, Shinkawa 6-20-2, Mitaka, Tokyo 181, Japan

Abbreviations: NSF, N-ethylmaleimide sensitive factor; SNAP, soluble NSF attachment protein; SNARE, SNAP receptor; FBS, fetal bovine serum; DMEM, Dulbecco's modified Eagle's medium; PBS, phosphate buffered saline. identified the basic components, such as synaptic vesicle-associated membrane proteins (v-SNAREs) and their cognate target membrane proteins ( $t$-SNAREs), of the machinery that control the targeting and fusion of synaptic vesicles with plasma membranes during the processes involved in the later exocytotic stage $[1,2]$. Characterization of these proteins and subsequent studies of their properties have led to a model called the SNARE hypothesis that explains vesicle docking and fusion [2]. Recently, several workers have shown that pancreatic beta cells, as well as neurons, express $\mathrm{N}$-ethylmaleimide sensitive factor $(\mathrm{NSF}), \alpha / \beta$ soluble NSF attachment proteins $(\alpha / \beta$ SNAP) and SNAP receptors (SNAREs) such as synaptotagmin, syntaxin and SNAP-25 [3-6]. Therefore, the SNARE hypothesis [7,8], which was proposed for the neurotransmitter release mechanism, may be applicable to insulin exocytosis in pancreatic beta cells, even though they are not identical to neurons. 
Insulin biosynthesis and release by pancreatic beta cells in the islets of Langerhans are regulated by glucose $[9,10]$, and stimulation of insulin release by glucose may increase the demand for $\alpha / \beta$ SNAP, NSF and SNAREs. For example, syntaxin $1 \mathrm{~A}$ may be recycled by plasma membranes and insulin secretory vesicles which are known to be dense core granules, as shown in chromaffin cells by Tagaya et al. [11], although there is no clear evidence of syntaxin 1A recycling in pancreatic beta cells. Furthermore, $\alpha / \beta S N A P$ may be a rate-limiting factor for insulin exocytosis as in neurotransmitter release [12-15]. Therefore, an increased demand for these proteins may be compensated for by parallel stimulation of the biosynthesis of syntaxin $1 \mathrm{~A}$ and $\alpha / \beta S N A P$ involved in glucosestimulated insulin exocytosis. In this study, we investigated whether or not glucose regulates syntaxin 1 and $\alpha / \beta$ SNAP biosynthesis by rat isolated pancreatic islets and the insulinoma cell line, $\beta$ TC3.

\section{Materials and methods}

Materials. Dulbecco's modified Eagle's medium (DMEM), RPMI 1640 and fetal bovine serum (FBS) were obtained from GIBCO BRL (Gaithersburg, USA). RPMI 1640 medium with different glucose concentrations was prepared using the selected amine kit from GIBCO BRL. Amplify was from Amersham Corporation (Amersham, Bucks., UK), and the protein labelling mix EXPRE ${ }^{35} \mathrm{SS}\left({ }^{35} \mathrm{~S}\right.$-methionine/cysteine) was purchased from Dupont NEN (New England Nuclear, Boston, Mass., USA). Protein A-Sepharose was from Pharmacia (Piscataway, N.J., USA). Actinomycin D was from Sigma (St. Louis, Mo., USA).

Islet isolation and culture of $\beta T C 3$ cells. Pancreatic islets from male, $200 \mathrm{~g}$, Wistar rats were isolated by collagenase digestion, as described previously [16], and picked up under a dissecting microscope. For the experiments with different glucose concentrations, the islets were incubated in PRMI 1640 medium containing $10 \%$ (v/v) dialysed FBS and the required glucose concentration for the required time under an atmosphere of $5 \% \mathrm{CO}_{2}$ and $95 \% \mathrm{O}_{2}$ at $37^{\circ} \mathrm{C}$. The $\beta \mathrm{TC} 3$ cells, a gift from Dr. D. Hanahan (University of California, San Francisco, Calif., USA), were cultured and maintained in DMEM, as described previously [17].

Antibodies. Mouse monoclonal antibody against rat syntaxin $1 \mathrm{~A} / \mathrm{Hpc}-1$ was obtained from Sigma. In order to study the specificity of this antibody, recombinant syntaxin 1a protein was produced as described previously [18]. The affinitypurified anti- $\alpha / \beta$-SNAP antiserum produced in rabbits using the $\alpha / \beta$-SNAP synthetic peptide was a generous gift from Dr. M. Takahashi (Mitsubishi Kasei Institute of Life Sciences, Tokyo, Japan). The antiserum against this peptide reacted with both recombinant bovine $\alpha$ - and mouse $\beta$-SNAP proteins produced by Escherichia coli M15 (data not shown).

Metabolic labelling. For metabolic labelling, unless otherwise stated, batches of $100-200$ islets or $0.5-1 \times 10^{6} \beta$ TC 3 cells were labelled in a $0.2-\mathrm{ml}$ reaction mixture comprising methionine/cysteine/leucine-free RPMI 1640 containing $10 \%$ (v/v) dialysed FBS and the required glucose concentration with
$100 \mu \mathrm{Ci}$ each of $\left[{ }^{35} \mathrm{~S}\right]$ methionine/cysteine and $\left[{ }^{3} \mathrm{H}\right]$ leucine for $3 \mathrm{~h}$ at $37^{\circ} \mathrm{C}$. After labelling, the islets or $\beta \mathrm{TC} 3$ cells were centrifuged briefly at $10000 \mathrm{rev} / \mathrm{min}$, the labelling medium was removed and the pellets were washed once with ice-cold phosphate buffered saline (PBS).

Immunoprecipitation. Labelled cell pellets were extracted by sonication in $0.1 \mathrm{ml}$ of TAS buffer $(0.1 \mathrm{~mol} / 1$ Tris- $\mathrm{HCl}$, $0.05 \mathrm{~mol} / 1 \mathrm{NaCl}, 0.25 \%$ (w/v) bovine serum albumin, $0.1 \%$ (v/v) Triton X-100, pH 7.5) containing a cocktail of protease inhibitors $(1 \mathrm{mmol} / \mathrm{l}$ phenylmethylsulfonyl fluoride, $50 \mu \mathrm{g} / \mathrm{ml}$ trasylol, $10 \mu \mathrm{g} / \mathrm{ml}$ leupeptin, and $5 \mu \mathrm{g} / \mathrm{ml}$ pepstatin A). Nuclei and insoluble debris were pelleted by centrifugation for $5 \mathrm{~min}$ in a microcentrifuge and the supernatant (total cell lysate) was collected, preadsorbed with preimmune rabbit or mouse serum by incubation with protein A-Sepharose beads for $2 \mathrm{~h}$ at $4^{\circ} \mathrm{C}$ and then subjected to immunoprecipitation with protein A-Sepharose beads with the required antiserum for $24 \mathrm{~h}$ at $4{ }^{\circ} \mathrm{C}$. The resulting Sepharose pellets were washed twice with ice-cold wash buffer $(0.6 \mathrm{~mol} / \mathrm{l} \mathrm{NaCl}, 10 \mathrm{mmol} / \mathrm{l}$ Tris $(\mathrm{pH} 8.6), 0.05 \%$ Nonidet P-40 and $0.1 \%$ sodium dodecyl sulfate (SDS) ) and once with ice-cold TS buffer $(0.1 \mathrm{~mol} / \mathrm{l}$ Tris- $\mathrm{HCl}, 0.05 \mathrm{~mol} / \mathrm{l} \mathrm{NaCl}$, $\mathrm{pH}$ 7.6). The pellets were eluted from the Sepharose by boiling with reducing SDS sample buffer and analysed by one-dimensional SDS electrophoresis on a $12 \%$ polyacrylamide gel. After fixation, the gels were prepared for fluorography by treatment with Amplify, dried, autoradiographed and the band intensities were quantified by laser scanning densitometry (Image Master version 1.20; Pharmacia Biotech).

Immunoblot analysis. For immunoblotting, 200 islets were lysed as described above, the proteins were separated by electrophoresis and transferred to nitrocellulose membrane filters in a blotting buffer consisting of $25 \mathrm{mmol} / \mathrm{l}$ Tris, $190 \mathrm{mmol} / \mathrm{l}$ glycine and $20 \%(\mathrm{v} / \mathrm{v})$ methanol. Non-specific antibody binding was blocked by incubating each filter with $5 \%$ non-fat dried milk in PBS. Next the filters were incubated with the required primary antibody (1:500-1000 dilution) for $4 \mathrm{~h}$, washed twice with $0.05 \%$ Nonidet P-40 and $0.1 \%$ Tween 20 in PBS, then incubated with horseradish peroxidase-conjugated secondary antibody for $1 \mathrm{~h}$. Finally, the bands were visualized using a chemiluminescence detection system (NEN).

Insulin biosynthesis and total protein synthesis. Prior to immunoprecipitation, $10 \mu \mathrm{l}$ aliquots were taken from each cell lysate for insulin immunoprecipitation using a guinea pig anti-insulin antibody (DAKO, Glostrup, Denmark), as described elsewhere [17]. Total protein synthesis was determined by precipitating the cell lysates with $10 \%$ (v/v) trichloroacetic acid, solubilizing the resulting pellets in $3 \mathrm{~mol} / \mathrm{l}$ acetic acid and counting their radioactivity using a liquid scintillation counter.

Northern blot analysis. We subjected $30 \mu \mathrm{g}$ of the total RNA isolated from mouse $\beta$ TC 3 cells to a $1.5 \%$ agarose, $0.66 \mathrm{~mol} / 1$ formaldehyde gel, blotted onto nitrocellulose filters, and hybridized with ${ }^{32} \mathrm{P}$-labelled mouse syntaxin $1 \mathrm{~A}$ cDNA probe. The filters were washed $(0.1 \times$ standard sodium citrate, $0.1 \%$ SDS, $55^{\circ} \mathrm{C}$ ), and exposed to Kodak X-Omat AR film at $-80^{\circ} \mathrm{C}$.

Statistical analysis. Data are presented as means \pm SEM. The significance of differences between groups was determined by analysis of variance (ANOVA) and those at $p<0.05$ were considered significant. 


\section{Results}

In experiments designed to investigate the effects of glucose on syntaxin $1, \alpha / \beta$ SNAP and proinsulin biosynthesis, rat isolated islets were radiolabelled for $3 \mathrm{~h}$. In order to analyse syntaxin 1 and $\alpha / \beta$ SNAP protein biosynthesis, lysates of labelled islets were immunoprecipitated with anti-syntaxin 1 and anti- $\alpha / \beta$ SNAP antibodies, then subjected to SDS-polyacrylamide gel electrophoresis (PAGE) followed by autoradiography. Before analysing the biosynthesis study, we checked the specificities of antibodies and performed the antibody titration study. Figure 1 demonstrated the specificities of these antibodies. They reacted with syntaxin 1 and $\alpha / \beta$ SNAP proteins, respectively, and the addition of an excess amount of recombinant proteins completely displaced the endogenous proteins. We deduced that the syntaxin 1 protein band which migrated to about $35 \mathrm{kDa}$ was syntaxin $1 \mathrm{~A}$, because we previously demonstrated that only syntaxin $1 \mathrm{~A}$, but not syntaxin $1 \mathrm{~B}$ can be amplified by RT-PCR [18]. The molecular mass of $\alpha / \beta$ SNAP was approximately $35 \mathrm{kDa}$ in our gel analysis. Although the molecular masses of $\alpha$ - and $\beta$-SNAP in neuronal tissues were reported to be 33 and $34 \mathrm{kDa}$, respectively $[12,19]$, our gel analysis did not enable us to establish whether this protein band was $\alpha$ - or $\beta$ SNAP or a combination of both. In order to establish the ability of antibodies to precipitate the syntaxin 1 and $\alpha / \beta$ SNAP proteins by immunoprecipitation method, $10 \mathrm{ng}$ and $1 \mu \mathrm{g}$ of syntaxin 1 and $\alpha$-SNAP recombinant proteins were immunoprecipitated with anti-syntaxin 1 and anti- $\alpha / \beta$-SNAP antibodies, respectively. Immunoprecipitants were analysed by immunoblot analysis with corresponding antibodies. Both antibodies were able to precipitate at least $1 \mu \mathrm{g}$ of recombinant proteins (Fig.2). Although the data are not shown, immunoblot analysis of supernatants did not show any detectable band of either protein, indicating that all recombinant protein was precipitated. Since immunoblot analysis of cell lysates of 200 islets showed only weakly stained bands of syntaxin 1 and $\alpha / \beta$ SNAP (Fig. 2), these antibodies were confirmed to precipitate all endogenous proteins of syntaxin 1 and $\alpha / \beta$-SNAP in islets by an immunoprecipitation method.

Glucose stimulated syntaxin 1A biosynthesis specifically in a manner similar to its stimulation of proinsulin (Fig. 3). Stimulation was detected with glucose in excess of $5.5 \mathrm{mmol} / \mathrm{l}$ and reached the maximum at concentrations over $11 \mathrm{mmol} / \mathrm{l}$ and the maximal stimulation of syntaxin 1 biosynthesis was about 8-fold. In contrast, $\alpha / \beta$ SNAP biosynthesis was affected little over the range of glucose concentrations used (only a 2-3-fold increase). The glucose-stimulated biosynthesis of $\alpha / \beta$ SNAP followed that of total islet protein (about a 2-fold increase). Next, we investigated the effects of actinomycin D, an inhibitor of mRNA

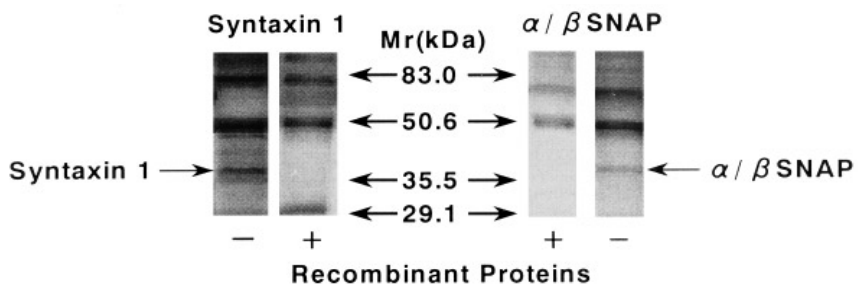

Fig. 1. Immunoprecipitation analysis of syntaxin 1 and SNAP proteins in rat isolated islets. We isolated 200 rat islets by collagenase digestion and radiolabelled for $3 \mathrm{~h}$ with ${ }^{35} \mathrm{~S}-\mathrm{Met} / \mathrm{Cys}$ and ${ }^{3} \mathrm{H}$-leucine in RPMI 1640 containing $10 \%$ (v/v) dialysed FBS in the presence of $5.5 \mathrm{mmol} / \mathrm{l}$ glucose. The islets were disrupted, immunoprecipitated with anti-syntaxin 1 and antiSNAP antibodies in the presence and absence of $10 \mu \mathrm{g}$ of recombinant proteins, as described in Materials and methods, and the immunoprecipitates were analysed using $12 \%$ SDSPAGE, followed by fluorography with Amplify and autoradiography

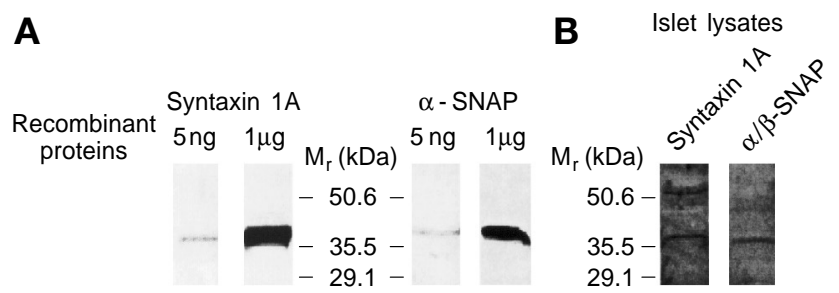

Fig. 2 A, B. Titration study of antibodies and immunoblot analysis of syntaxin 1 and $\alpha / \beta$ SNAP in rat islets. A) Titration study: $10 \mathrm{ng}$ and $1 \mu \mathrm{g}$ of recombinant syntaxin 1 and $\alpha$ SNAP proteins, produced by E.coli and purified, were immunoprecipitated with anti-syntaxin 1 and anti- $\alpha / \beta$-SNAP antibodies, respectively. The pellets were dissolved in reducing SDS sample buffer and analysed by $12 \%$ SDS-PAGE, then transferred to a nitrocellulose filter. The filter was reacted with corresponding antibodies and the band was visualized using a chemiluminescence detection system. B) Immunoblot analysis of rat islets: Total cell lysates from 200 islets were subjected to immunoblot analysis, as described in Materials and methods, using specific anti-syntaxin 1 and anti- $\alpha / \beta$-SNAP antisera

synthesis [20]. Radiolabelling of rat isolated islets for $3 \mathrm{~h}$ in the presence of actinomycin D affected neither glucose-stimulated syntaxin 1 nor proinsulin biosynthesis (Table 1), indicating that glucose regulation was predominantly at the translational level. The stimulation of both syntaxin 1 and proinsulin biosynthesis by glucose was time-dependent (Fig. 4). Significant stimulation of proinsulin biosynthesis was detected within $20 \mathrm{~min}$ of preincubation, whereas that of syntaxin 1 was not detected until after $2 \mathrm{~h}$ of preincubation and increased with time thereafter, reaching a steady-stimulated-state after $3 \mathrm{~h}$ of preincubation (Fig. 4). Thus, the patterns of syntaxin 1 and proinsulin biosynthesis differed over time, but the effects of glucose were specific and their patterns were not identical to that of total protein synthesis.

We also investigated whether glucose regulates syntaxin 1 and $\alpha / \beta$ SNAP biosynthesis by the mouse 


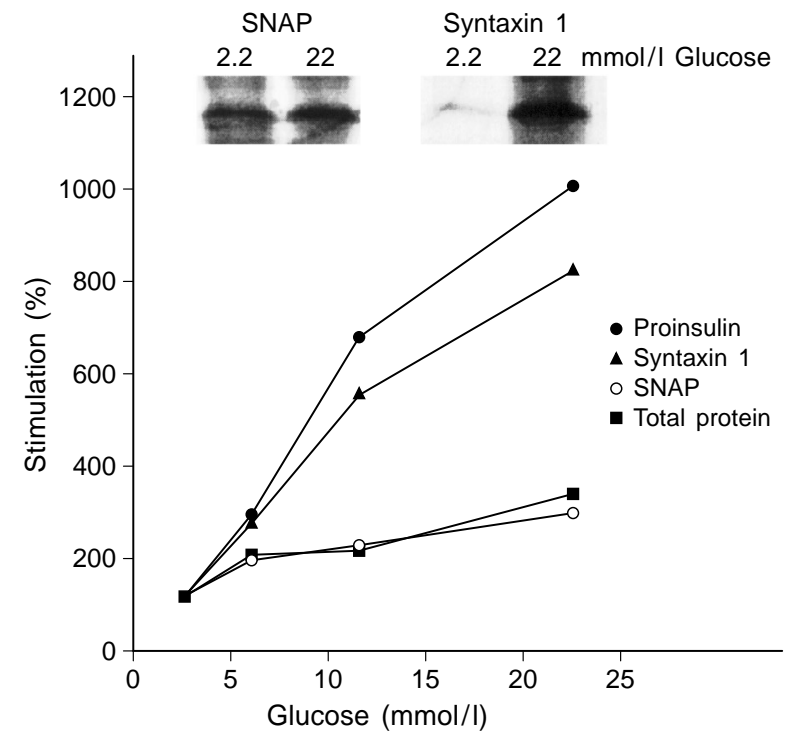

Fig.3. Dose-dependent stimulation of proinsulin, syntaxin 1 and $\alpha / \beta$ SNAP biosynthesis by glucose. Rat isolated islets were incubated for $3 \mathrm{~h}$ with the indicated glucose concentrations in the presence of ${ }^{35} \mathrm{~S}-\mathrm{Met} / \mathrm{Cys}$ and ${ }^{3} \mathrm{H}$-leucine. Proinsulin and total protein synthesis were measured, as described in Materials and methods. Syntaxin 1 and $\alpha / \beta$ SNAP were immunoprecipitated from islet lysates with specific antisera and analysed by $12 \%$ SDS-PAGE followed by fluorography and densitometric analysis. The results are expressed as arbitrary scan units, relative to values obtained in the presence of basal $(2.2 \mathrm{mmol} / \mathrm{l})$ glucose. The means of five separate experiments are shown. Insert shows a typical autoradiogram of syntaxin 1 and $\alpha / \beta$ SNAP protein analysed by immunoprecipitation

insulinoma cell line $\beta \mathrm{TC} 3$, by which insulin secretion and biosynthesis were found to respond to glucose after a long incubation period [17]. After preincubation for 3 or $24 \mathrm{~h}$ with either 0 or $11 \mathrm{mmol} / \mathrm{l}$ glucose, $\beta$ TC3 cells were radiolabelled for $3 \mathrm{~h}$ in the presence of the same glucose concentration. Syntaxin 1 and $\alpha / \beta$ SNAP biosynthesis after preincubation for $3 \mathrm{~h}$ in the presence or absence of $11 \mathrm{mmol} / \mathrm{l}$ glucose did not differ, but the biosynthetic rates of cells preincubated with $11 \mathrm{mmol} / \mathrm{l}$ glucose for $24 \mathrm{~h}$ were about 3 times higher than those of cells preincubated without glucose (Table 2). In fact, Northern blot analysis with rat syntaxin $1 \mathrm{~A}$ cDNA probe showed that the level of syntaxin $1 \mathrm{~A}$ mRNA in cells treated with a high

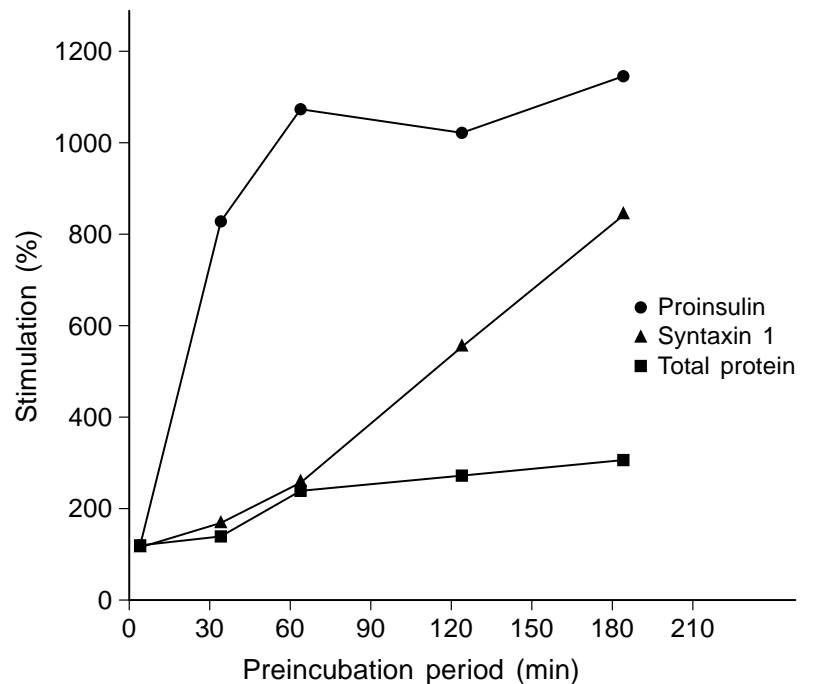

Fig. 4. Time courses of glucose-stimulated proinsulin and syntaxin 1 biosynthesis. Rat isolated islets were maintained in the presence of $2.2 \mathrm{mmol} / \mathrm{l}$ glucose for $1 \mathrm{~h}$, then preincubated for the indicated times with $22 \mathrm{mmol} / \mathrm{l}$ glucose, after which, they were labelled with ${ }^{35} \mathrm{~S}-\mathrm{Met} / \mathrm{Cys}$ and ${ }^{3} \mathrm{H}$-leucine for $45 \mathrm{~min}$ in the presence of $22 \mathrm{mmol} / \mathrm{l}$ glucose. Proinsulin and syntaxin 1 were immunoprecipitated with specific antisera and analysed as described in Materials and methods. The results are expressed as values relative to those obtained at the start of the preincubation period $(0 \mathrm{~min})$. The means of 3 separate experiments are shown

glucose concentration increased compared to that in non-glucose-treated cells only after a $24 \mathrm{~h}$ preincubation period (Fig. 5). The pattern of glucose-stimulated proinsulin biosynthesis by $\beta$ TC 3 cells was similar to the syntaxin 1 and $\alpha / \beta$ SNAP biosynthetic patterns. Accordingly, syntaxin 1 and $\alpha / \beta$ SNAP biosynthesis by $\beta$ TC3 cells was regulated by glucose in a similar manner to that observed in proinsulin biosynthesis.

\section{Discussion}

Recently, it was demonstrated that syntaxin $1[18,21]$ and $\alpha$-SNAP [22] perform specialized roles in insulin secretion, indicating that these proteins must be synthesized and assembled in a co-ordinated manner to ensure integrated functioning of the organelle. As

Table 1. Effect of actinomycin D on glucose-stimulated proinsulin, syntaxin 1 , and $\alpha / \beta$ SNAP biosynthesis

\begin{tabular}{lllll}
\hline & \multicolumn{4}{l}{ Increase (-fold) relative to $2.2 \mathrm{mmol} / \mathrm{l}$ glucose } \\
\cline { 2 - 5 } & Proinsulin & Syntaxin 1 & $\alpha / \beta$ SNAP & Total protein \\
\hline -Actinomycin D & $11.5 \pm 1.5$ & $8.6 \pm 1.8$ & $3.1 \pm 1.1$ & $2.8 \pm 0.5$ \\
Actinomycin D $(10 \mu \mathrm{mol} / \mathrm{l})$ & $10.3 \pm 2.3$ & $7.0 \pm 1.3$ & $2.6 \pm 0.8$ & $2.1 \pm 0.6^{\mathrm{a}}$ \\
\hline
\end{tabular}

Isolated rat islets were incubated for $3 \mathrm{~h}$ in 22 or $2.2 \mathrm{mmol} / \mathrm{l}$ glucose \pm actinomycin D with $\left[{ }^{35} \mathrm{~S}\right]$ Met-Cys and $\left[{ }^{3} \mathrm{H}\right]$-Leucine. Proinsulin, syntaxin 1 , and $\alpha / \beta$ SNAP were immunoprecipitated from islet lysates as described in Materials and methods. Total protein synthesis was determined by trichloroacetic acid
$(10 \%(\mathrm{v} / \mathrm{v}))$ precipitation. Results (mean \pm SEM for 3-5 experiments) are expressed relative to values obtained at a basal $2.2 \mathrm{mmol} / \mathrm{l}$ glucose

${ }^{\mathrm{a}} p<0.05$ vs actinomycin D 
Table 2. Glucose regulation of proinsulin, syntaxin 1 and $\alpha / \beta$ SNAP biosynthesis by $\beta T C 3$ cells

\begin{tabular}{lllll}
\hline $\begin{array}{l}\text { Incubation } \\
\text { period }\end{array}$ & \multicolumn{4}{l}{ Increase (-fold) relative to $0 \mathrm{mmol} / \mathrm{l}$ glucose } \\
\cline { 2 - 5 } & Proinsulin & Syntaxin 1 & $\alpha / \beta$ SNAP & Total protein \\
\hline $3 \mathrm{~h}$ & $1.1 \pm 0.5$ & $0.9 \pm 0.3$ & $1.4 \pm 0.1$ & $1.2 \pm 0.3$ \\
$24 \mathrm{~h}$ & $2.1 \pm 0.3$ & $3.3 \pm 0.8$ & $3.4 \pm 1.1$ & $1.9 \pm 0.5$ \\
\hline
\end{tabular}

$\beta$ TC3 cells were incubated for 3 or $24 \mathrm{~h}$ in RPMI 1640 medium containing $\pm 11 \mathrm{mmol} / \mathrm{l}$ glucose. After incubation, the medium was removed and cells were then labelled for $3 \mathrm{~h}$ with $\left[{ }^{35} \mathrm{~S}\right]$ Met-Cys and $\left[{ }^{3} \mathrm{H}\right]$ Leucine in the presence of the same glucose concentration as that used before incubation. Proinsulin, syntaxin 1 , and $\alpha / \beta$ SNAP were immunoprecipitated from total cell lysates as described in Materials and methods. Results (mean \pm SEM for 3 experiments) are expressed as relative to values obtained at $0 \mathrm{mmol} / \mathrm{l}$ glucose

insulin biosynthesis is regulated by glucose predominantly at the level of preproinsulin mRNA translation $[9,10]$, the biosynthetic control exerted by glucose appears to extend to these proteins. At present, it is not known whether these proteins respond to glucose in a similar manner to proinsulin.

In this study, we investigated the effects of glucose on syntaxin 1 and $\alpha / \beta$ SNAP biosynthesis by radiolabelled rat islets and $\beta$ TC 3 cells using immunoprecipitation analysis. Our results indicated that syntaxin 1, but not $\alpha / \beta$ SNAP biosynthesis is regulated in coordination with proinsulin biosynthesis by rat isolated islets. Glucose stimulated syntaxin 1 biosynthesis in a manner similar to its stimulation of proinsulin biosynthesis and glucose regulation of syntaxin 1 mimicked that of proinsulin biosynthesis. the magnitudes of the glucose-stimulated syntaxin 1 and proinsulin biosynthetic responses were almost the same, whereas those of the glucose-stimulated $\alpha / \beta$ SNAP and total protein synthetic responses were almost identical. Although it is conceivable that glucose directly stimulated syntaxin 1 biosynthesis, it may increase the immunogenicity of syntaxin 1 to the antibody instead of direct biosynthetic stimulation, since this protein is known to be part of a multiprotein complex [23-25]. Northern blot analysis with syntaxin 1 cDNA probe may provide an answer to this question. However, Northern blot data by rat islets did not show an appreciable amount of syntaxin 1 mRNA because of its extremely low level of expression in islets (data not shown). Although syntaxin 1 biosynthesis required a relatively long time (about $3 \mathrm{~h}$ ) to reach a steady state, incubation with actinomycin $\mathrm{D}$ did not affect its rate, suggesting that translational control was operational. Indeed, the specific regulation of proinsulin biosynthesis by glucose occurred predominantly at a translational level $[9,26]$. Biosynthesis of several secretory granule proteins [27], as well as PC3 endopeptidase $[28,29]$, is also stimulated specifically by glucose at a translational level. One possible mechanism involves an increase in the rate of signal recognition

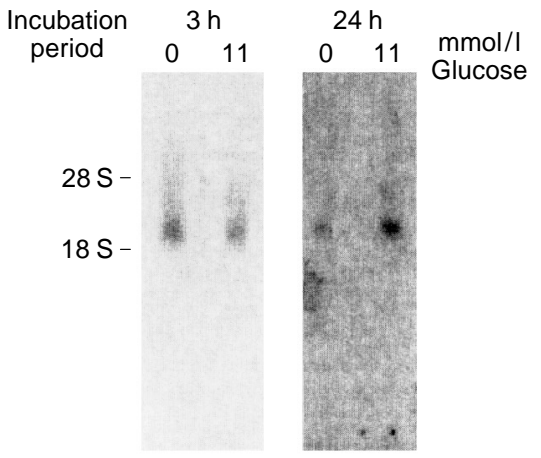

Fig.5. Northern blot analysis of syntaxin 1 A mRNA in mouse $\beta$ TC3 cells. After $\beta$ TC3 cells were treated with and/or without $11 \mathrm{mmol} / \mathrm{l}$ glucose for 3 or $24 \mathrm{~h}$, total cellular RNAs were isolated and $30 \mu \mathrm{g}$ samples were electrophoresed, transferred to a nitrocellulose filter, and hybridized with ${ }^{32} \mathrm{P}$-labelled syntaxin 1 cDNA probe. The autoradiogram was exposed for 4 days

particle-mediated translocation of nascent peptides into the endoplasmic reticulum lumen, as proposed for insulin synthesis [26]. In agreement with this hypothesis, glucose did not stimulate $\alpha / \beta$ SNAP biosynthesis selectively, as this cytoplasmic protein is presumably synthesized on free ribosomes. However, this hypothesis does not completely fit the mechanism responsible for glucose-regulated syntaxin 1 biosynthesis, because the membrane-spanning region of syntaxin 1 is localized at the extreme $\mathrm{COOH}$-terminal [30, 31], indicating that synthesis would be completed by the ribosomes before the transmembrane region was recognized by signal recognition particle. Syntaxin 1 may be inserted post-translationally into endoplasmic reticulum membranes [32], by the interaction with signal recognition particles or other molecules. Indeed, Jantti et al. [33] indicated that yeast syntaxin Sso2p predominantly uses a posttranslational endoplasmic reticulum insertion mechanism, but whether the insertion process involves signal recognition particles, or some other, yet unidentified protein translocation machinery, remains to be determined. Thus, the mechanisms responsible for glucose-regulated syntaxin 1 and insulin biosynthesis may not be the same and the different time courses of glucose-regulated syntaxin 1 and proinsulin biosynthesis shown in Figure 4 appear to represent the different mechanisms, however the mechanism remains largely obscure.

On the other hand, the data yielded by the insulinoma cell line $\beta$ TC3 experiments showed that glucose stimulated both syntaxin 1 and $\alpha / \beta$ SNAP biosynthesis to almost the same extent. Glucose stimulated the biosynthesis of these proteins only after a 24-h preincubation period, similar to its stimulation of proinsulin biosynthesis. As demonstrated previously [17], glucose only regulates proinsulin biosynthesis by insulinoma $\beta \mathrm{TC} 3$ cells at the transcriptional 
level, because these cells have lost selectively the translational control of insulin biosynthesis, as have RINm5F cells [34] and it is noteworthy that the regulation pattern of proinsulin biosynthesis by $\beta \mathrm{TC} 3$ cells followed those of syntaxin 1 and $\alpha / \beta$ SNAP biosynthesis. Indeed, the data of Northern blot analysis of syntaxin 1A mRNA indicated that glucose increased syntaxin $1 \mathrm{~A}$ biosynthesis at the transcriptional level by a mechanism similar to that of proinsulin biosynthesis. The reason why $\alpha / \beta$ SNAP biosynthesis is regulated by glucose in parallel to that of proinsulin only in $\beta$ TC3 cells is not known at present. As mentioned above, insulin biosynthesis in $\beta$ TC 3 cells responded only after prolonged exposure to glucose, and these cells do not have a secretory pathway regulated by the physiological concentration of glucose observed in intact islets. Accordingly, the different glucose-regulated process of syntaxin/ $\alpha / \beta \mathrm{SNAP} /$ proinsulin observed in $\beta \mathrm{TC} 3$ cells appears to represent a marked characteristic difference between insulinoma cell line and primary islet cells.

It is of interest that glucose stimulated syntaxin 1 biosynthesis by rat islets and $\beta$ TC 3 cells, because syntaxin $1 \mathrm{~A}$ overproduction by $\beta$ TC3 cells inhibited glucose-stimulated insulin release [18]. In view of its function as a negative regulator, glucose would be expected to regulate syntaxin 1 biosynthesis negatively. However, we would like to emphasize that syntaxin 1A functions in the insulin exocytotic pathway, whether as a negative or positive regulator, and must be an important part of the insulin exocytotic machinery. Therefore, it would not be surprising if glucose did upregulate syntaxin 1 biosynthesis. Indeed, treatment of rat islets with an anti-syntaxin 1 antibody inhibited, rather than stimulated, insulin release [21]. Although the physiological significance of glucosestimulated syntaxin 1 biosynthesis in rat islets is still to be determined, it is conceivable that glucose-stimulated the syntaxin 1 biosynthesis in order to compensate for the deficit of this protein in glucose-stimulated insulin exocytosis if syntaxin 1 plays a role in the storage of secretory granules as proposed by Bittner et al. [35]. On the other hand, as $\alpha / \beta$ SNAP protein was shown to stimulate hormone release from permeabilized adrenal chromaffin [12] and insulin secreting [22] cells, stimulation of $\alpha / \beta$ SNAP biosynthesis by glucose is easier to understand. However, as shown above, glucose did not stimulate $\alpha / \beta$ SNAP biosynthesis by rat islets selectively in the short term incubation, probably because $\alpha / \beta$ SNAP protein in the cytoplasm is stable and rapid production may not be necessary.

In conclusion, glucose selectively stimulated syntaxin $1 \mathrm{~A}$ and proinsulin biosynthesis in parallel by rat islets. This may be key element of the insulin exocytotic machinery that enable pancreatic beta cells to maintain constant levels of the proteins that comprise the exocytotic machinery.
Acknowledgements. We thank A.Nakahara for assistance in the preparation of the manuscript. This study was supported in part by a grant-in-aid from the Japan Private School Promotion Foundation (to S.N.), and Scientific Research (B) 08457057 from the Ministry of Education, Science and Culture, and "Research for the Future" Program JSPS-RFTF 97I00201 from the Japan Society for the Promotion of Science.

\section{References}

1. Rothman JE (1994) Mechanisms of intracellular protein transport. Nature 374: 55-63

2. Südhof TC (1995) The synaptic vesicle cycle: a cascade of protein-protein interactions. Nature 375: 645-653

3. Jacobsson G, Bean AJ, Scheller RH et al. (1994) Identification of synaptic proteins and their isoform mRNAs in compartments of pancreatic endocrine cells. Proc Nat Acad Sci (USA) 91: 12487-12491

4. Sadoul K, Lang J. Montecucco C et al. (1995) SNAP-25 is expressed in islets of Langerhans and is involved in insulin release. J Cell Biol 128: 1019-1028

5. Boyd RS, Duggan MJ, Shone CC, Foster KA (1995) The effect of botulinum neurotoxins on the release of insulin from the insulinoma cell lines HIT-15 and RIN m5F. J Biol Chem 270: $18216-18218$

6. Oho C, Seino S, Takahashi M (1995) Expression and complex formation soluble N-ethyl-maleimide-sensitive factor attachment protein (SNAP) receptors in clonal rat endocrine cells. Neurosci Lett 186: 208-210

7. Söllner T, Bennett MK, Whiteheart SW, Scheller RH, Rothman JE (1993) A protein assembly - disassembly pathway in vitro that may correspond to sequential steps of synaptic vesicle docking, activation, and fusion. Cell 75: 409-418

8. Rothman JE, Warren G (1994) Implications of SNARE hypothesis for intracellular membrane topology and dynamics. Curr Biol 4: 220-233

9. Kaelin D, Renold AE, Sharp GWG (1978) Glucose stimulated proinsulin biosynthesis: rates of turn off after cessation of the stimulus. Diabetologia 14: 329-335

10. Ashcroft SJH, Bunce J, Lowry M, Hansen SE, Hedeskov CJ (1978) The effect of sugars on (pro)insulin biosynthesis. Biochem J 174: 517-526

11. Tagaya M, Toyonaga S, Takahashi M et al. (1995) Syntaxin 1 (HPC-1) is associated with chromaffin granules. J Biol Chem 270: 15930-15933

12. Morgan A, Burgoyne RD (1995) A role for soluble NSF attachment proteins (SNAPs) in regulated exocytosis in adrenal chromaffin cells. EMBO J 14: 232-239

13. Victoria Kibble A, Barnard RJO, Burgoyne RD (1996) Patch-clamp capacitance analysis of the effects of $\alpha$-SNAP on exocytosis in adrenal chromaffin cells. J Cell Sci 109: 2417-2422

14. Sudlow AW, McFerran BW, Bodill H, Barnard RJO, Morgan A, Burgoyne RD (1996) Similar effects of $\alpha$ - and $\beta$ SNAP on $\mathrm{Ca}^{2+}$-regulated exocytosis. FEBS Lett 393: 185188

15. Calakos N, Scheller RH (1996) Synaptic vesicle biogenesis, docking, and fusion: a molecular description. Physiol Rev 76: $1-29$

16. Nagamatsu S, Grodsky GM (1988) Glucose-regulated proinsulin processing in isolated islets from rat pancreas. Diabetes 37: 1426-1431

17. Nagamatsu S, Steiner DF (1992) Altered glucose regulation of insulin biosynthesis in insulinoma cells: mouse 
$\beta$ TC3 cells secrete insulin-related peptides predominantly via a constitutive pathway. Endocrinology 130: 748-754

18. Nagamatsu S, Fujiwara T, Nakamichi Y et al. (1996) Expression and functional role of syntaxin 1/HPC-1 in pancreatic $\beta$ cells; syntaxin $1 \mathrm{~A}$, but not $1 \mathrm{~B}$, plays a negative role in regulatory insulin release pathway. J Biol Chem 271: 11601165

19. Whiteheart SW, Griff IC, Brunner M et al. (1993) SNAP family of NSF attachment proteins includes a brain-specific isoform. Nature 362: 353-355

20. Permutt MA, Kipnis DM (1972) Insulin biosynthesis. I. On the mechanism of glucose stimulation. J Biol Chem 247: 1194-1199

21. Martin F, Moya F, Gutierrez LM, Reig JA, Soria B (1995) Role of syntaxin in mouse pancreatic beta cells. Diabetologia 38: 860-863

22. Kiraly-Borri CE, Morgan A, Burgoyne RD, Weller U, Wollheim CB, Lang J (1996) Soluble N-ethylmaleimidesensitive-factor attachment protein and N-ethylmaleimide-sensitive factors are required for $\mathrm{Ca}^{2+}$-stimulated exocytosis of insulin. Biochem J 314: 199-203

23. Calakos N, Bennett MK, Peterson KE, Scheller RH (1994) Protein-protein interactions contributing to the specificity of intracellular vesicular trafficking. Science Wash DC 263: 1146-1149

24. Chapman ER, An S, Barton N, Jahn R (1994) SNAP-25, a t-SNARE which binds to both syntaxin and synaptobrevin via domains that may form coiled coils. J Biol Chem 269: 27427-27432

25. Otto H, Hanson PI, Jahn R (1997) Assembly and disassembly of a ternary complex of synaptobrevin, syntaxin, and SNAP-25 in the membrane of synaptic vesicles. Proc Natl Acad Sci USA 94: 6197-6201

26. Welsh M, Scherberg N, Gilmore R, Steiner DF (1986) Translational control of insulin biosynthesis: evidence for regulation of elongation, initiation and signal recognition particle-mediated translational arrest by glucose. Biochem J 235: 459-467

27. Guest PC, Bailyes EM, Rutherford NG, Hutton JC (1991) Insulin secretory granule biogenesis: co-ordinate regulation of the biosynthesis of the majority of constituent proteins. Biochem J 274: 73-78

28. Alarcon C, Lincoln B, Rhodes CJ (1993) The biosynthesis of the subtilisin-related proprotein convertase PC3, but not that of the PC2 convertase, is regulated by glucose in parallel to proinsulin biosynthesis in rat pancreatic islets. $\mathbf{J}$ Biol Chem 268: 4276-4280

29. Martin SK, Carroll R, Benig M, Steiner DF (1994) Regulation by glucose of the biosynthesis of $\mathrm{PC} 2, \mathrm{PC} 3$ and proinsulin in $(o b / o b)$ mouse islets of Langerhans. FEBS Lett 356: $279-282$

30. Inoue A, Obata K, Akagawa K (1992) Cloning and sequence analysis of cDNA for a neuronal cell membrane antigen, HPC-1. J Biol Chem 267: 10613-10619

31. Bennett MK, Garcia-Arraras JE, Elferink LA et al. (1993) The syntaxin family of vesicular transport receptors. Cell 74: 863-873

32. Heijne GV (1988) Transcending the impenetrable: how proteins come to terms with membranes. Biochem Biophys Acta 947: 307-333

33. Jantti J, Keranen S, Toikkanen J et al. (1994) Membrane insertion and intracellular transport of yeast syntaxin Sso2p in mammalian cells. J Cell Sci 107: 3623-3633

34. Nielsen DA, Welsh M, Casadaben MJ, Steiner DF (1985) Control of insulin gene expression in pancreatic $\beta$-cells and in an insulin-producing cell line, RIN-5F cells. I. Effects of glucose and cyclic AMP on the transcription of insulin mRNA. J Biol Chem 260: 13585-13589

35. Bittner MA, Bennett MK, Holz RW (1996) Evidence that syntaxin $1 \mathrm{~A}$ is involved in storage in the secretory pathway. J Biol Chem 271: 11214-11221 